\title{
Grzyby podziemne Pienińskiego Parku Narodowego - nowe dane o różnorodności i rozmieszczeniu
}

\author{
Piotr ChachuŁa, Piotr Mleczko, Izabela A. Wierzbowska i Wiktoria Kędzior
}

\begin{abstract}
ChachuŁa, P., Mleczko, P., Wierzbowska, I. And KęDzior, W. 2020. Hypogeous fungi of Pieniny National Park - new data on diversity and distribution. Fragmenta Floristica et Geobotanica Polonica 27(2): 359-378. Kraków. e-ISSN 2449-8890, ISSN 1640-629X.

ABstRact: The diversity of hypogeous fungi in the Pieniny Mts has been insufficiently studied. Until recently, eight species were known from this area. The aim of the present study was to gather new data on the hypogeous fungal mycobiota of this mountain range. In July and September of 2016 and 2017, sporocarps of hypogeous fungi were searched on six permanent plots established in Pieniny National Park. The dominant plant associations were beech and beech-fir forest with spruce, hazel, hornbeam and elm as accompanying trees. Over 100 samples of hypogeous fungi were gathered during the field work. They included 30 species from ascomycete genera: Elaphomyces (3 species), Genea (1), Hydnobolites (1), Hydnocystis (1), Hydnotrya (1), Leucangium (1), Pachyphlodes (1), Tuber (4), and basidiomycetes: Chamonixia (1), Gautieria (3), Hymenogaster (5), Hysterangium (5), Melanogaster (2) and Octaviania (1). Nine species were most frequent: Hysterangium nephriticum, Melanogaster broomeanus, Hydnobolites cerebriformis, Hydnocystis piligera, Hymenogaster rehsteineri, $H$. cf. megasporus, Hysterangium stoloniferum and Gautieria morchelliformis. Three species are first records for Poland: Hydnocystis piligera, Hymenogaster cf. arenarius and $H$. cf. megasporus. The hypogeous mycobiota of the Pieniny Mts now numbers 35 species.
\end{abstract}

KeY WORDS: fungal diversity, Pieniny Mts, Polish mycobiota

P. Chachuła, Pieniński Park Narodowy, ul. Jagiellońska 107B, 34-450 Krościenko nad Dunajcem, Polska; e-mail: piotrekchacha@gmail.com

P. Mleczko (autor korespondencyjny), W. Kędzior, Instytut Botaniki, Uniwersytet Jagielloński wKrakowie, Gronostajowa 3,30-387 Kraków,Polska; e-mail piotr.mleczko@uj.edu.pl

I. Wierzbowska, Instytut Nauk o Środowisku, Uniwersytet Jagielloński w Krakowie, ul. Gronostajowa 7, 30-387 Kraków, Polska; e-mail: i.wierzbowska@uj.edu.pl

\section{WSTĘP}

Grzyby podziemne (hypogeiczne) to specyficzna grupa grzybów makroskopijnych, którą wyróżnia szereg adaptacji morfologicznych i ekologicznych (HAWKER 1954; ŁAWRYNOWICZ 1988; LÆSSøE \& HANSEN 2007; OBERWINKLER 2012). Grzyby te cechuje wytwarzanie zarodników w obrębie zamkniętych lub częściowo otwartych owocników, które tworzą się i dojrzewają w podłożu (glebie). Większość grzybów podziemnych utraciła zdolność aktywnego uwalniania zarodników, a podziemne środowisko, w którym dojrzewają, uniemożliwia 
rozprzestrzenianie zarodników z prądami powietrza. Głównym sposobem dyspersji na średnie oraz dalekie dystanse jest transport przez organizmy wektorowe, przede wszystkim stawonogi, mięczaki oraz zwierzęta kręgowe, głównie ssaki (URBAN 2015; ZAMBONELLI i in. 2017). Przejście przez przewód pokarmowy zwierząt najprawdopodobniej również ułatwia kiełkowanie zarodników (LUOMA i in. 2003; FrANK i in. 2006; URBAN 2015).

Grzyby podziemne pełnią ważną rolę w łańcuchach troficznych, stanowiąc pokarm dla mykofagicznych zwierząt oraz wchodząc w interakcje z symbiotycznymi roślinami (CLARIDGE \& TRAPPE 2005; URBAN 2015; ZAMBONELLi i in. 2017). Zdecydowana większość tych grzybów to symbionty ektomykoryzowe głównie drzew, jednak znane są również relacje endomykoryzowe z innymi roślinami, zwłaszcza storczykami, np. w przypadku niektórych gatunków trufli, Tuber spp. (OuANPHANIVANH i in. 2008). Zwierzęta spożywające owocniki grzybów mykoryzowych mogą mieć wpływ na rozwój siedlisk leśnych oraz ich sukcesję na obszarach nieleśnych, na których nie ma inokulum grzybów mykoryzowych w postaci zarodników i grzybni, poprzez dostarczanie zarodników z odchodami (CLARIDGE i in. 1999; Frank 2005; SCHICKMANN i in. 2012; SidLAR 2012).

Pieniny charakteryzuje bogata w gatunki i dobrze poznana mykobiota. Ten stosunkowo niewielki teren, dzięki urozmaiceniu orograficznemu i wapiennemu podłożu, jest miejscem występowania gatunków grzybów wyjątkowych w skali kraju i Europy (CHACHuŁA 2012). Na obszarze Pienińskiego Parku Narodowego (PPN) do 2015 r. odnotowano 1041 gatunków grzybów makroskopijnych, w tym 881 gatunków grzybów podstawkowych i 158 workowych i 2 grzyby sprzężniowe (GUMIŃsKA 2000; CHACHUŁA 2016) oraz ponad 500 gatunków grzybów mikroskopijnych (KUĆMIERZ 1976a, b). Mimo dobrego rozpoznania mykobioty,

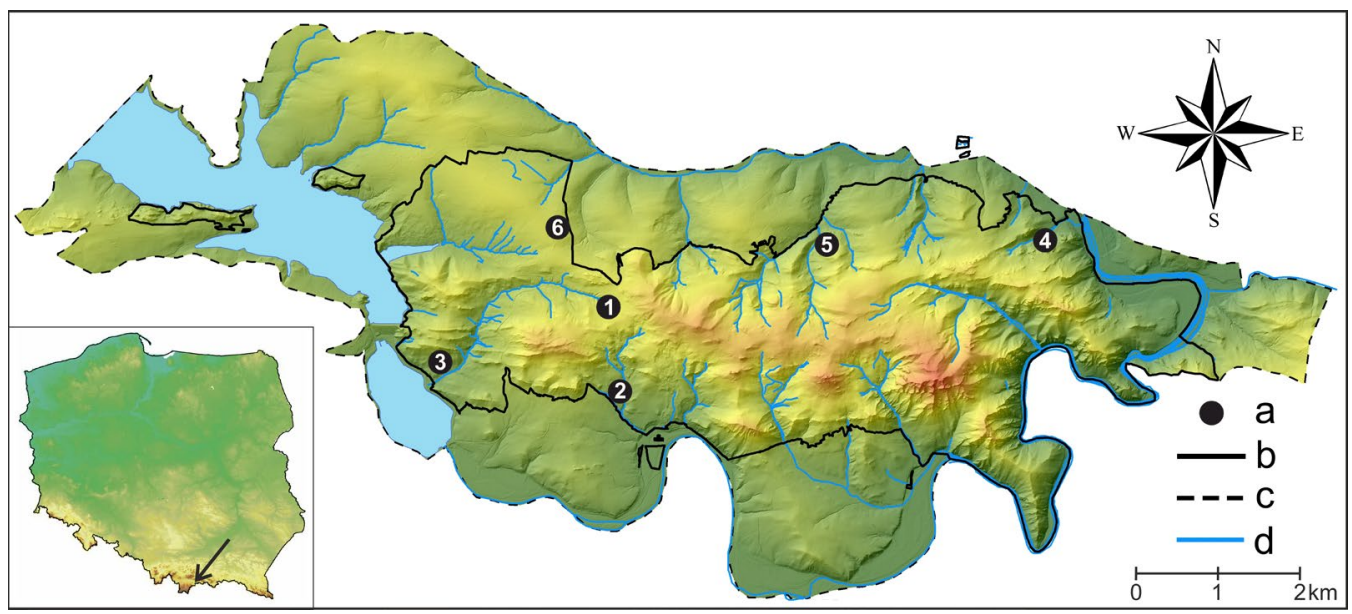

Ryc. 1. Lokalizacja powierzchni, na których prowadzono poszukiwania owocników grzybów podziemnych na terenie Pienińskiego Parku Narodowego. a - powierzchnie: 1 - Pod Szkółką, 2 - Gróbka, 3 - Upszar, 4 - Dolina Ociemnego Potoku, 5 - Zagroń-Biały Potok, 6 - Majerz (Osica, Lasek); b - granica PPN; c - granica otuliny PPN; d - cieki wodne

Fig. 1. Location of plots in Pieniny National Park on which the sporocarps of hypogeous fungi were searched. a - plots: 1 - Pod Szkółką (below forest nursery), 2 - Gróbka, 3 - Upszar, 4 - Dolina Ociemnego Potoku (Ociemny Potok valley), 5 - Zagroń-Biały Potok, 6 - Majerz (Osica, Lasek); b - borders of Pieniny National Park; c - boundaries of the buffer zone of Pieniny NP; $d$ - watercourses 
do 2000 r. z obszaru Pienin podawano w literaturze jedynie cztery gatunki grzybów podziemnych: Choiromyces meandriformis Vittad. (LuBELSKA 1953, jako C. venosus (Fr.) Th. Fr.), Elaphomyces asperulus Vittad. (GumińsKA 1990), Rhizopogon roseolus (Corda) Th. Fr. (GuMiŃSKA 1972) oraz Hysterangium crassum (Tul. \& C. Tul.) E. Fisch. (GuMińsKa 1970, 1972, jako H. separabile Zeller). W ciągu kolejnych dziewiętnastu lat odnotowano jeszcze cztery gatunki: Hysterangium stoloniferum Tul. \& C. Tul. i Russula mattiroloana (Cavara) T. Lebel (Komur i in. 2019; Vidal i in. 2019) oraz dwa nowe dla nauki - Diversispora sporocarpia Chachuła, Mleczko, Zubek, Niezgoda, Kozłowska, Jobim, B.T. Goto \& Błaszk. i Russula candidissima J.M. Vidal, Pasabán \& Chachuła (JoBIm i in. 2019; VIDAL i in. 2019).

Celem podjętych badań było poszerzenie wiedzy o różnorodności i stanowiskach grzybów podziemnych na terenie PPN oraz uzyskanie danych stanowiących odniesienie dla wyników analizy obecności grzybów podziemnych w diecie małych ssaków (KomUR i in. 2020). Badania prowadzone były w ramach projektu „Różnorodność i wzajemne powiązania pomiędzy gryzoniami a grzybami podziemnymi i ich wpływ na środowisko przyrodnicze Pienińskiego Parku Narodowego", finansowanego przez Fundusz Leśny Państwowego Gospodarstwa Leśnego Lasy Państwowe.

\section{TEREN I METODY BADAŃ}

\section{Teren badań}

Badania przeprowadzono w Pienińskim Parku Narodowym, w centralnej części Pienin (Karpaty Zachodnie). Pasmo Pienin od północy sąsiaduje z Gorcami i Beskidem Sądeckim, a od południa z Magurą Spiską. Najwyższy szczyt w PPN to Okrąglica (982 m n.p.m.), znajdująca się w masywie Trzech Koron. Na obszarze Parku (2371 ha) przeważają utwory wapienne, są również margle i iłowce. Na utworach tych wytworzyły się głównie rędziny, pararędziny, które zajmują ok. $60 \%$ powierzchni, i gleby brunatne - ok. $30 \%$ powierzchni.

Klimat tego obszaru charakteryzuje się raczej niskimi średnimi rocznymi opadami wynoszącymi ok. 700-900 mm i dość wysoką średnią temperaturą, z najzimniejszym miesiącem styczniem, ze średnią temperaturą $-6^{\circ} \mathrm{C}$, i najcieplejszym lipcem, ze średnią temperaturą wynoszącą $16^{\circ} \mathrm{C}$. W Pieninach wyróżniono dwa piętra klimatyczne: umiarkowanie ciepłe, ze średnią temperaturą ok. $6-8^{\circ} \mathrm{C}$ oraz umiarkowanie zimne, ze średnią temperaturą ok. $4-6^{\circ} \mathrm{C}$ (PIENIŃSKI PARK NAROdOWY 2018).

\section{Materiał i metody}

Poszukiwanie owocników grzybów podziemnych prowadzono na sześciu leśnych powierzchniach badawczych (pow.) o powierzchni ok. $10000 \mathrm{~m}^{2}$ (1 ha) każda, założonych w ramach wspomnianego wyżej projektu w następujących zbiorowiskach leśnych (Tab. 1): jedlina karpacka wariant typowy (pow. 1.) i florystycznie ubogi (pow. 5.), ciepłolubna jedlina wariant typowy (pow. 2., 3.) i wariant florystycznie ubogi (pow. 2.), buczyna karpacka podzespół typowy wariant typowy (pow. 4.). Na powierzchni 6. znajdował się drzewostan iglasty pochodzący z nasadzenia. Na większości powierzchni dominowały lub stanowiły domieszkę drzewa ektomykoryzowe: jodła (Abies alba), świerk (Picea abies), leszczyna (Corylus avellana) i buk (Fagus sylvatica), nieobecny jedynie na powierzchni 6. w rejonie Majerz (Osica, Lasek). $\mathrm{Na}$ niektórych powierzchniach towarzyszyły im również grab (Carpinus betulus), wiąz górski (Ulmus glabra), modrzew europejski (Larix decidua) i sosna zwyczajna (Pinus sylvestris) (Tab. 1). W obrębie powierzchni przebiegały transekty, na których rozlokowane były pułapki wykorzystywane do odłowów małych ssaków (Tab. 1). 
Tabela 1. Charakterystyka siedliskowa powierzchni, na których prowadzone były poszukiwania grzybów podziemnych. Współrzędne geograficzne wyznaczają środek transektu biegnącego przez powierzchnię (patrz rozdział Metody)

Table 1. Habitat characteristics of the plots on which hypogeous fungi sporocarps were searched. Geographic coordinates determine the center of the transect running through the plot (see chapter Methods)

\begin{tabular}{lc}
\hline \hline $\begin{array}{l}\text { Powierzchnia } \\
\text { (Plot) }\end{array}$ & $\begin{array}{c}\text { Ekspozycja południowa } \\
\text { (Southern exposure) }\end{array}$ \\
\hline
\end{tabular}

1. Pod szkółką

$49^{\circ} 25^{\prime} 24,7^{\prime \prime} \mathrm{N} ; 20^{\circ} 21^{\prime} 26,38^{\prime \prime} \mathrm{E}$

2. Gróbka

$49^{\circ} 24^{\prime} 50,63^{\prime \prime} \mathrm{N} ; 20^{\circ} 21^{\prime} 56,29^{\prime \prime} \mathrm{E}$

3. Upszar (rejon Głębokiego Potoku) $49^{\circ} 24^{\prime} 56,3^{\prime \prime} \mathrm{N}$; $20^{\circ} 19^{\prime} 52,65^{\prime \prime} \mathrm{E}$

4. Dolina Ociemnego Potoku $49^{\circ} 25^{\prime} 49,16^{\prime \prime} \mathrm{N} ; 20^{\circ} 26^{\prime} 3,84^{\prime \prime} \mathrm{E}$

5. Zagroń-Biały Potok

$49^{\circ} 25^{\prime} 46,94^{\prime \prime} \mathrm{N} ; 20^{\circ} 23^{\prime} 41,27^{\prime \prime} \mathrm{E}$

6. Majerz (Osica, Lasek)

$49^{\circ} 25^{\prime} 55,22^{\prime \prime} \mathrm{N} ; 20^{\circ} 21^{\prime} 9,32^{\prime \prime} \mathrm{E}$
Jedlina karpacka wariant typowy Dentario glandulosae-Fagetum abietetosum var. typicum. W drzewostanie dominuje jodła z domieszką świerka i buka. W podszycie głównie jodła, świerk i leszczyna

(Montane forb-rich Carpathian fir-beech forest, typical variant, Dentario glandulosae-Fagetum abietetosum var. typicum. Tree layer dominated by fir with admixture of beech and spruce. Fir, spruce and hazel in the understory)

Ciepłolubna jedlina wariant typowy Carici albae-Fagetum abietetosum var. typicum i ciepłolubna jedlina wariant florystycznie ubogi Carici albae-Fagetum abietetosum. W drzewostanie dominuje świerk i jodła z domieszką buka, jesiona i wiąza górskiego. W podszycie głównie świerk i leszczyna

(Thermophilous fir forest Carici albae-Fagetum abietetosum, typical (var. typicum) and poor variants. Tree layer dominated by spruce, fir with admixture of beech, European ash, and Scotch elm. Spruce and hazel in the understory)

Ciepłolubna jedlina wariant typowy Carici albae-Fagetum abietetosum var. typicum. W drzewostanie dominuje świerk i jodła z domieszką buka. W podszycie głównie świerk i leszczyna

(Thermophilous fir forest, typical variant, Carici albae-Fagetum abietetosum var. typicum. Tree layer dominated by spruce, fir with admixture of beech. Spruce and hazel in the understory)

Ekspozycja północna

(Northern exposure)

Buczyna karpacka podzespół typowy wariant typowy Dentario glandulosae-Fagetum typicum var. typicum. W drzewostanie dominuje jodła i buk z domieszką grabu i jawora. W podszycie głównie leszczyna (Montane forb-rich Carpathian fir-beech forest, typical variant, Dentario glandulosae-Fagetum abietetosum var. typicum. Tree layer dominated by fir and beech with admixture of hornbeem and sycamore. Hazel in the understory)

Jedlina karpacka wariant florystycznie ubogi Dentario glandulosae-Fagetum abietetosum. W drzewostanie dominuje jodła i buk z domieszką jawora. W podszycie głównie jodła i leszczyna

(Montane forb-rich Carpathian fir-beech forest, floristically poor variant, Dentario glandulosae-Fagetum abietetosum. Tree layer dominated by fir and beech with admixture of sycamore. Fir and hazel in the understory)

Drzewostan z nasadzenia bez gatunków wskaźnikowych w runie. W drzewostanie dominuje jodła, świerk, modrzew i sosna z domieszką jawora. W podszycie głównie jodła, świerk i leszczyna

(Planted coniferous forest, with spruce, fir, pine and larch with admixture of sycamore. Fir, spruce and hazel in the understory) 
Poszukiwania owocników grzybów przeprowadzano pod koniec każdej sesji odłowów gryzoni, w lipcu i wrześniu 2016 i 2017 r. Identyfikacja owocników została oparta na współczesnych kluczach i pracach monograficznych: Alvarado i in. (2016), CAstellano (1989), Halász i in. (2005), MonteCchi \& SaraSINI (2000), PAZ i in. $(2016,2017)$ oraz STIELOw i in. (2010, 2011). Cechy makroskopowe obserwowano na świeżych i suchych okazach. Cechy mikroskopowe obserwowano na preparatach sporządzonych z eksykatów, umieszczonych w wodzie (używanych zawsze do wykonywania pomiarów zarodników), 3\% KOH i odczynniku Melzera, przy wykorzystaniu mikroskopu optycznego ZEISS AxioScope A.1, wyposażonego w system DIC oraz aparat cyfrowy (AxioCam MRc5). Pomiary struktur mikroskopowych wykonano za pomocą komputerowego oprogramowania do akwizycji i analizy obrazu ZEN 2012, blue edition (Carl Zeiss Microscopy). Dane zostały oparte na 20-30 pomiarach. W przypadku wymiarów zarodników podano średnią oraz wartości skrajne. Przy gatunkach podawanych w niniejszej pracy jako nowe dla Polski zamieszczono krótki opis najważniejszych cech makro- i mikroskopowych. Eksykaty owocników przechowywane są w Zielniku Instytutu Botaniki Uniwersytetu Jagiellońskiego w Krakowie (KRA). Nazwy grzybów podano według MYcoBAnK (www.mycobank.org), nazwy roślin według MirKa i in. (2002), a nazwy zbiorowisk roślinnych według PANCER-KoteJoweJ i in. (2004).

\section{WYNIKI}

\section{Różnorodność owocników grzybów podziemnych}

Na powierzchniach zebrano łącznie 108 prób owocników grzybów podziemnych, 36 z powierzchni nr 1 (Pod Szkółką), 14 z powierzchni nr 2 (Gróbka), 30 z powierzchni nr 3 (Upszar, w rejonie Głębokiego Potoku), 7 z powierzchni nr 4 (Dolina Ociemnego Potoku), 20 z powierzchni nr 5 (Zagroń-Biały Potok). Na powierzchni nr 6 (Majerz) nie stwierdzono owocników grzybów podziemnych. Zidentyfikowano 30 gatunków należących do 8 rodzajów grzybów workowych: Elaphomyces (3 gatunki), Genea (1), Hydnobolites (1), Hydnocystis (1), Hydnotrya (1), Leucangium (1), Pachyphlodes (1) i Tuber (4) oraz 6 rodzajów grzybów podstawkowych: Chamonixia (1), Gautieria (3), Hymenogaster (5), Hysterangium (5), Melanogaster (2) i Octaviania (1) (Tab. 2).

\section{Lista gatunków}

Gatunki podano w układzie alfabetycznym z podziałem na grzyby workowe (Ascomycota) i podstawkowe (Basidiomycota). Stanowiska grzybów wymieniono w kolejności wynikającej z numeracji powierzchni, na których się znajdowały. Oprócz numeru i nazwy powierzchni wymieniono autora kolekcji, datę zbioru i numery kolekcji zielnikowych. W uwagach zawarto informacje o ekologii gatunku, a przy gatunkach, których identyfikacja może stwarzać problemy, również uwagi o charakterystycznych cechach morfologicznych owocników. Dane o rozmieszczeniu zostały uwzględnione z okresu po 1945 r., chyba że do tej pory znane były jedynie stanowiska historyczne. W przypadku grzybów podawanych z Polski po raz pierwszy zamieszczono krótki opis najważniejszych makro- i mikroskopowych cech owocników.

Stosowane skróty: Q - stosunek długości zarodników do ich szerokości, PC - Piotr Chachuła, PM Piotr Mleczko, PK - Patryk Komur, ${ }^{*}$ - gatunek niepodawany dotychczas z terenu Pienin, ${ }^{* *}$ gatunek niepodawany dotychczas z terenu Polski. 
Tabela 2. Lista gatunków grzybów podziemnych i ich stanowiska (numeracja stanowisk jak w Tab. 1)

Table 2. List of hypogeous fungal species and their localities (numbering of localities as in Tab. 1)

\begin{tabular}{|c|c|c|}
\hline $\begin{array}{l}\text { Przynależność systematyczna } \\
\text { (Systematic position) }\end{array}$ & $\begin{array}{l}\text { Gatunek } \\
\text { (Species) }\end{array}$ & $\begin{array}{l}\text { Powierzchnie } \\
\quad \text { (Plots) }\end{array}$ \\
\hline \multicolumn{3}{|l|}{ ASCOMYCOTA } \\
\hline \multicolumn{3}{|l|}{ Eurotiales } \\
\hline \multirow[t]{3}{*}{ Elaphomycetaceae } & Elaphomyces asperulus Vittad. & 5 \\
\hline & Elaphomyces granulatus Fr. & 5 \\
\hline & Elaphomyces muricatus Fr. s.1. & 5 \\
\hline \multicolumn{3}{|l|}{ Pezizales } \\
\hline Discinaceae & Hydnotrya tulasnei (Berk.) Berk. \& Broome & 1,5 \\
\hline Helvellaceae & Leucangium carthusianum (Tul. \& C. Tul.) Paol. & 4 \\
\hline \multirow[t]{2}{*}{ Pezizaceae } & Pachyphlodes conglomerata (Berk. \& Broome) Dowel & 3 \\
\hline & Hydnobolites cerebriformis Tul. \& C. Tul. & $1,2,3$ \\
\hline \multirow[t]{2}{*}{ Pyronemataceae } & Genea hispidula Berk. ex Tul. \& C. Tul. & \\
\hline & Hydnocystis piligera Tul. & $1,3,5$ \\
\hline \multirow[t]{4}{*}{ Tuberaceae } & Tuber foetidum Vittad. & 2 \\
\hline & Tuber fulgens Quél. & 3 \\
\hline & Tuber puberulum Berk. \& Broome & 2,5 \\
\hline & Tuber rufum var. rufum Picco & 2 \\
\hline \multicolumn{3}{|l|}{ BASIDIOMYCOTA } \\
\hline \multicolumn{3}{|l|}{ Agaricales } \\
\hline \multirow[t]{5}{*}{ Hymenogastraceae } & Hymenogaster $\mathrm{cf}$. arenarius Tul. \& C. Tul. & 4 \\
\hline & Hymenogaster citrinus Vittad. & 2,3 \\
\hline & Hymenogaster griseus Vittad. & 3 \\
\hline & Hymenogaster cf. megasporus Soehner & $1,2,3$ \\
\hline & Hymenogaster rehsteineri Bucholtz & $2,3,4$ \\
\hline \multicolumn{3}{|l|}{ Boletales } \\
\hline \multirow[t]{2}{*}{ Boletaceae } & Chamonixia caespitosa Rolland & 1 \\
\hline & Octaviania mutabilis E. Bommer \& M. Rousseau & 5 \\
\hline \multirow[t]{2}{*}{ Paxillaceae } & Melanogaster ambiguus (Vittad.) Tul. \& C. Tul. & 1,5 \\
\hline & Melanogaster broomeanus Berk. & $1,2,3,4$ \\
\hline \multicolumn{3}{|l|}{ Gomphales } \\
\hline \multirow[t]{3}{*}{ Gomphaceae } & Gautieria graveolens Vittad. & 1,3 \\
\hline & Gautieria morchelliformis Vittad. & $1,3,5$ \\
\hline & Gautieria trabutii (Chatin) Pat. & 1,5 \\
\hline \multicolumn{3}{|l|}{ Hysterangiales } \\
\hline \multirow[t]{5}{*}{ Hysterangiaceae } & Hysterangium clathroides Vittad. & 1 \\
\hline & Hysterangium coriaceum $\mathrm{R}$. Hesse & 1 \\
\hline & Hysterangium crassum (Tul. \& C. Tul.) E. Fisch. & \\
\hline & Hysterangium nephriticum Berk. & $1,2,4,5$ \\
\hline & Hysterangium stoloniferum Tul. \& C. Tul. & $1,3,4$ \\
\hline
\end{tabular}




\section{ASCOMYCOTA}

\section{Elaphomyces asperulus Vittad.}

Stanowisko: 1. Zagroń-Biały Potok, leg. PC, 12.08.2016, KRA F-2016-1.

Uwagi: owocniki znajdowane głównie w lasach iglastych i mieszanych, znacznie rzadziej w liściastych; gatunek bardzo częsty w Polsce, szczególnie w południowej części kraju, w obszarach górskich (ŁAWRYNOWICZ 1988; KUJAWA 2018), podawany również z Pienin (GuMIŃSKA 1990).

\section{*Elaphomyces granulatus Fr.}

Stanowisko: 1. Zagroń-Biały Potok, leg. PC, 12.08.2016, KRA F-2016-154.

Uwagi: gatunek związany z drzewami iglastymi i liściastymi, w różnego typu lasach, częsty; rozpowszechniony na terenie całego kraju (ŁAWRYNOWICZ 1988; KUJAWA 2018).

\section{"Elaphomyces muricatus s.l. Fr.}

Stanowisko: 1. Zagroń-Biały Potok, leg. PC, 12.08.2016, KRA F-2016-2.

Uwagi: takson zbiorczy, w ostatniej rewizji rodzaju Elaphomyces z terenu Europy został podzielony na kilka gatunków, których dokładna identyfikacja opiera się na drobnych cechach i wymaga badań molekularnych (PAz i in. 2017). Występuje zarówno w lasach iglastych, jak i liściastych, zazwyczaj głęboko w podłożu; w Polsce znany z wielu stanowisk (ŁaWrYNOWICZ 1988; KuJAWA 2018).

*Genea hispidula Berk. ex Tul. \& C. Tul.

Stanowisko: 1. Upszar (rejon Głębokiego Potoku), leg. PK i PM, 31.07.2016, KRA F-2016-55.

Uwagi: gatunek związany z drzewami liściastymi, w różnego typu lasach, owocniki zazwyczaj występują płytko pod powierzchnią ściółki. W Polsce znany z kilkudziesięciu stanowisk (ŁAWRYNOWICZ 1988, 1990; ŁaWryNOWICZ i in. 2002a, 2002b; AdAMCZYK 2007, 2009; Pietras i in. 2016; WoJewOda i in. 2016).

\section{*Hydnobolites cerebriformis Tul. \& C. Tul.}

Stanowiska: 1. Pod Szkółką, leg. PK i PM, 31.07.2016, KRA F-2016-62. 2. Gróbka, leg. PK i PM, 31.07.2016, KRA F-2016-61. 3. Upszar (rejon Głębokiego Potoku), leg. PK i PM, 31.07.2016, KRA F-2016-50, KRA F-2016-60, KRA F-2016-63; leg. PC, 31.07.2016, KRA F-2016-59.

Uwagi: rośnie zarówno w lasach iglastych, jak i liściastych, owocniki często rozwijają się w ściółce lub tuż pod nią. Znany współcześnie z kilkunastu stanowisk, m.in. z Wyżyny Krakowsko-Częstochowskiej i z Cieszyna (ŁaWrynowicz 1988; ChachuŁa i in. 2015).

\section{**Hydnocystis piligera Tul.}

Stanowisko: 1. Pod Szkółką, leg. PK i PM, 21.07.2017, KRA F-2017-30, KRA F-2017-36. 2. Upszar (rejon Głębokiego Potoku), leg. PK i PM, 31.07.2016, KRA F-2016-64. 3. Zagroń-Biały Potok, leg. PK i PM, 30.07.2016, KRA F-2016-65.

Owocniki okrągławe do spłaszczonych, średnicy 0,5-3(4) $\mathrm{cm}$, powierzchnia blado żółtoochrowa, owłosiona; wnętrze stanowi jedna komora wypełniona watowatą białawą grzybnią; perydium psudopa-

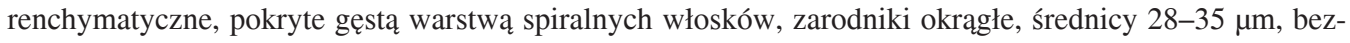
barwne, cienkościenne, gładkie.

Uwagi: gatunek związany z drzewami liściastymi; w regionie śródziemnomorskim podawany również spod drzew iglastych. 


\section{"Hydnotrya tulasnei (Berk.) Berk. \& Broome}

Stanowisko: 1. Pod Szkółką, leg. PK i PM, 25.07.2016, KRA F-2016-66. 2. Zagroń-Biały Potok, leg. PK i PM, 20.07.2017, KRA F-2017-54.

Uwagi: gatunek związany z drzewami liściastymi (bukiem, dębem); głównie na niżu i w niższych położeniach górskich, jeden z częstszych grzybów podziemnych w Polsce (ŁaWRYNOWICZ 1988, 1990; Stasińska 1994, 2000; AdAMCZYK 1996, 2003a, b, 2007, SZKodZiK 2005; AdAMCZYK i in. 2008; WoJEWODA 2008; ŁAWRYNOWICZ i in. 2009; PIETRAS i in. 2016; KuJAWA i in. 2017). Do niedawna traktowany był szeroko, łącznie z H. bailii Soehner, związanym z drzewami iglastymi (głównie świerkiem) i traktowanym obecnie jako oddzielny takson (STIELOW i in. 2010).

\section{${ }^{*}$ Leucangium carthusianum Tul. \& C. Tul.}

Stanowisko: 1. Dolina Ociemnego Potoku, leg. PC, 11.08.2016, KRA F-2016-10.

Uwagi: rośnie głównie w lasach górskich w pobliżu buka, jodły i świerka. Gatunek w Polsce znany jedynie z Dłubniańskiego Parku Krajobrazowego na Wyżynie Krakowsko-Częstochowskiej (CHACHUŁA 2018).

\section{*Pachyphlodes conglomerata (Berk. \& Broome) Doweld}

Syn.: Pachyphloeus conglomeratus Berk. \& Broome

Stanowisko: 1. Upszar (rejon Głębokiego Potoku), leg. PK i PM, 31.07.2016, KRA F-2016-57.

Uwagi: gatunek związany z drzewami liściastymi; z Polski podawany z czterech stanowisk w centrum kraju (Kujawa \& GiercZYK 2011). Według MonteCCHIEGO i SARAsiniego (2000) jego cechami charakterystycznymi są: gładkie perydium, długie worki (do $250 \mu \mathrm{m})$ i brodawkowane zarodniki.

\section{"Tuber foetidum Vittad.}

Stanowisko: 1. Gróbka, leg. PC, 16.08.2016, KRA F-2016-8.

Uwagi: grzyb związany z drzewami liściastymi, występuje często na glebach wapiennych; w Polsce znany jedynie z Cieszyna (CHAchuŁa i in. 2020). Cechami wyróżniającymi ten gatunek spośród innych z grupy Puberulum są brodawkowata powierzchnia stosunkowo ciemno zabarwionych owocników, pseudoparenchymatyczna budowa perydium pozbawionego cystyd oraz ornamentacja zarodników w postaci siatki o nielicznych i dużych oczkach (ŁaWrYNowicz 1988; MonteCCHI \& SARASInI 2000; Halász i in. 2005).

\section{*Tuber fulgens Quél.}

Stanowisko: 1. Upszar (rejon Głębokiego Potoku), leg. PK i PM, 31.07.2016, KRA F-2016-34.

Uwagi: Gatunek związany z drzewami liściastymi, występuje na glebach zasadowych; w Polsce znany z kilku stanowisk w centralnej oraz południowej Polsce (ŁAWRYNOWICZ 2009, 2011; KUJAWA \& GIERCZYK 2011; RUtKowsKi i in. 2014; ChACHUŁA 2018; GIERCZYK i in. 2018).

\section{"Tuber puberulum Berk. \& Broome}

Stanowiska: 1. Gróbka, leg. PC, 16.08.2016, KRA F-2016-19, KRA F-2016-21. 2. Zagroń-Biały Potok, leg. PC, 12.08.2016, KRA F-2016-11.

Uwagi: gatunek związany z drzewami iglastymi, bez wyraźnych preferencji siedliskowych; w Polsce prawdopodobnie to jedna z najliczniej występujących trufli (ŁAWRYNOWICZ 1988, 2011; ADAMCZYK 1996; WoJEWODA i in. 2016). Cechą charakterystyczną T. puberulum są jasno zabarwione owocniki pokryte licznymi ostrymi włoskami. W budowie mikroskopowej cechuje je pseudoparenchymatyczne perydium, 
długie (do ponad $200 \mu \mathrm{m}$ ), ostro zakończone sety oraz okrąłe zarodniki z siateczkowatym urzeźbieniem z licznymi (do 7) oczkami (Ławrynowicz 1988; Montecchi \& SARAsini 2000; Halász i in. 2011).

\section{"Tuber rufum var. rufum Picco}

Stanowisko: 1. Gróbka, leg. PC, 16.08.2016, KRA F-2016-9.

Uwagi: gatunek spotykany zarówno w otoczeniu drzew iglastych, jak i liściastych; w Polsce podawany z kilku stanowisk w centralnej i południowej części kraju (ŁAWRYNOwICZ 1988, 2009, 2011; AdAMCZYK 1996; HilsZCZAŃSKa i in. 2008, 2014). Według MonTECChIEGo i SARASINIEGO (2000) cechą wyróżniającą odmianę typową $T$. rufum jest brązowoczerwone perydium pokryte płaskimi brodawkami, ŁAWRYNOWICZ (1988) wymienia jako cechę wyróżniającą również kolor gleby: cielista, z wiekiem czerwonobrązowa.

\section{BASIDIOMYCOTA}

\section{"Chamonixia caespitosa Rolland}

Stanowisko: 1. Pod Szkółką, leg. PC, 19.07.2017, KRA F-2017-42.

Uwagi: gatunek związany ze świerkiem i prawdopodobnie również jodłą, przede wszystkim w obszarach górskich; znany z licznych stanowisk przede wszystkim w polskich Karpatach (MLECZKo i in. 2009; KozAK i in. 2013; WoJewoda i in. 2016), a także z Sudetów (NARKIEwICZ i in. 2013). Takson łatwy do identyfikacji ze względu na intensywnie przebarwianie się owocników na kolor niebieski do granatowego.

\section{"Gautieria graveolens Vittad.}

Stanowisko: 1. Pod Szkółką, leg. PM i PK, 21.07.2017, KRA F-2017-13. 2. Upszar (rejon Głębokiego Potoku), leg. PM i PK, 10.10.2017, KRA F-2017-19.

Uwagi: gatunek występuje w wyżynnych i górskich lasach iglastych; jedyne znane współczesne stanowisko tego gatunku w Polsce znajduje się w Gorcach (WoJEWOdA i in. 2016). Według MonTECCHIEGO i SARASINIEGO (2000) owocniki G. graveolens są morfologicznie bardzo zbliżone do owocników G. morchelliformis - cechami wyróżniającymi ten takson są: szersze zarodniki $(\mathrm{Q}=1,7-1,8 ;$ G. morchelliformis: $\mathrm{Q}=2,0-2,2$ ), okrągławe lub wydłużone, ale najczęściej nierozgałęzione komory gleby (w owocnikach G. morchelliformis są najczęściej wydłużone i rozgałęzione) i wyraźna kolumella widoczna na przekroju owocników (w przypadku G. morchelliformis jest słabo widoczna).

\section{"Gautieria morchelliformis Vittad.}

Stanowiska: 1. Pod Szkółką, leg. PC, 19.07.2017, KRA F-2017-18; leg. PM i PK, 21.07.2017, KRA F-2017-7, KRA F-2017-11, KRA F-2017-16. 2. Upszar (rejon Głębokiego Potoku), leg. PM i PK, 10.10.2017, KRA F-2017-53. 3. Zagroń-Biały Potok, leg. PC, 29.08. 2017, KRA F-2017-46, 23.09.2017, KRA F-2017-17.

Uwagi: gatunek występujący w wyżynnych i górskich lasach iglastych, morfologicznie zbliżony do G. graveolens (por. powyżej); w Polsce znany z kilku stanowisk w centralnej i południowej części kraju (KuJAWA \& GierczyK 2010; WoJeWOda i in. 2016).

\section{"Gautieria trabutii Chatin}

Stanowisko: 1. Pod Szkółką, leg. PK i PM, 31.07.2016, KRA F-2016-56. 2. Zagroń-Biały Potok, leg. PC, 27.07. 2017, KRA F-2017-13. 
Uwagi: gatunek związany z drzewami liściastymi i iglastymi; w Polsce znany dotychczas tylko z Gorców (WoJEwOda i in. 2016). Według MonTECCHIEGo i SARASINIEGo (2000) charakteryzują go okrągłe pęcherzyki na zarodnikach, stanowiące element ornamentacji.

*Hymenogaster cf. arenarius Tul. \& C. Tul.

Syn.: Hymenogaster pusillus Berk. \& Broome

Stanowisko: 1. Dolina Ociemnego Potoku, leg. PC, 11.08.2016, KRA F-2016-12.

Owocniki okrąławe, pofałdowane, średnicy $0,5-2,5 \mathrm{~cm}$, perydium początkowo białoszare o błyszczącej powierzchni, potem brązowoszare, gleba zwarta, zbudowana z małych komór, dojrzała w odcieniach brązowordzawych; zarodniki wrzecionowate $(11,5) 15,5(18,5) \times(6,5) 8,5(10,5) \mu \mathrm{m}$, ornamentacja w postaci brodawek.

Uwagi: rośnie w otoczeniu drzew liściastych, preferuje luźne gleby piaszczyste. Według STIELOwA i in. (2011) H. arenarius należy do grupy gatunków wykształcających brodawkowate zarodniki o średniej długości poniżej $18 \mu \mathrm{m}$. Cechy odróżniające go od pozostałych gatunków w obrębie grupy to: perydium nie czysto białe (białe zabarwienie jest charakterystyczne dla $H$. tener Berk. i H. niveus Vittad.), większe wymiary zarodników (10)14(17) × (6)10(13) $\mu \mathrm{m}$ (w przypadku podobnego H. intermedius Stielow, Bratek \& Hensel: (10)12(14) $\times(6) 8(9) \mu \mathrm{m})$, szeroko wrzecionowate zarodniki pokryte delikatnym, brodawkowatym urzeźbieniem (owoidalne w przypadku $H$. intermedius). Owocniki $H$. cf. arenarius znaleziono w Pieninach latem, natomiast według STIELOwA i in. (2011) cechą typową dla tego gatunku jest tworzenie owocników wiosną.

\section{*Hymenogaster citrinus Vittad.}

Syn.: H. bucholtzii Soehner, H. olivaceus Vittad., H. tomentellus R. Hesse.

Stanowiska: 1. Gróbka, leg. PK i PM, 31.07.2016, KRA F-2016-85; leg. PC, 16.08.2016, KRA F-201614. 2. Upszar (rejon Głębokiego Potoku), leg. PK i PM, 31.07.2016, KRA F-2016-53, KRA F-2016-47, KRA F-2016-67, KRA F-2016-77, KRA F-2016-82, KRA F-2016-86, KRA F-2016-46, KRA F-2016-70, KRA F-2016-76; leg. PC, 31.07.2016, KRA F-2016-71.

Uwagi: gatunek związany z drzewami liściastymi, rzadziej iglastymi (np. sosną); współcześnie z Polski podawany z Beskidu Niskiego (CHACHUŁA i in. 2016) pod nazwą H. olivaceus, wspomniany został również przez JÜLICHA (1984), bez podawania stanowisk. Według STIElowa i in. (2011) cechy odróżniające H. citrinus od innych gatunków w obrębie rodzaju wykształcających gładkie zarodniki to: średnie wymiary zarodników $26 \times 13 \mu \mathrm{m}$ (H. luteus Vittad. $20 \times 9 \mu \mathrm{m}, H$. bulliardii Vittad. $20 \times 11 \mu \mathrm{m}$ ); wykształcanie wyraźniej papilli w odróżnieniu od tępo zakończonych zarodników H. luteus; otaczanie zarodników charakterystycznym perisporium, nieobecnym u zarodników $H$. bulliardii i H. luteus. Od H. megasporus, gatunku wykształcającego duże (średnia długość powyżej $24 \mu \mathrm{m}$ ), brodawkowate zarodniki, H. citrinus odróżnia obecność papilii, której brak na zarodnikach H. megasporus.

\section{${ }^{*}$ Hymenogaster griseus Vittad.}

Syn.: H. hessei Soehner, H. lycoperdineus Vittad., H. populetorum Tul. \& C. Tul., H. vulgaris Tul. \& C. Tul.. Według StiElowa i in. (2011) synonimy prawdopodobnie obejmują również: H. lilacinus Tul. \& C. Tul. i H. muticus Berk. \& Broome.

Stanowisko: 1. Upszar (rejon Głębokiego Potoku), leg. PC, 31.07.2016, KRA F-2016-83.

Uwagi: gatunek spotykany w otoczeniu drzew liściastych i iglastych, także w górach; z Polski podawany do tej pory jedynie ze stanowiska historycznego z okolic Elblaga (KAUFMANN 1925, jako H. vulgaris). Należy do grupy gatunków wykształcających zarodniki o średniej długości powyżej 18 i poniżej $24 \mu \mathrm{m}$. Według STIELOWA i in. (2011) od H. rehsteineri, gatunku wykształcającego na zarodnikach wyraźną papillę, H. griseus odróżnia urzeźbienie w postaci żeber i niepełnej siatki (brodawki i krótkie żebra, ale izolowane u H. rehsteineri) oraz mniej wysmukłe zarodniki $(\mathrm{Q}=1,7-2,1 ;$ H. rehsteineri: $\mathrm{Q}=2,1-2,3)$. 


\section{"Hymenogaster rehsteineri Bucholtz}

Syn.: H. decorus Tul. \& C. Tul.

Stanowiska: 1. Gróbka, leg. PC, 16.08.2016, KRA F-2016-13, KRA F-2016-16; leg. PK i PM, 31.07.2016, KRA F-2016-81. 2. Upszar (rejon Głębokiego Potoku), leg. PC, 31.07.2016, KRA F-2016-68, KRA F-2016-79; 3. Dolina Ociemnego Potoku, leg. PC, 11.08.2016, KRA F-2016-17.

Uwagi: rośnie w otoczeniu drzew liściastych, także w górach; do tej pory z Polski podawany jedynie z historycznych stanowisk na Dolnym Śląsku (SCHROETER 1889, jako H. decorus). Gatunek należy do grupy w obrębie rodzaju Hysterangium, którą cechują zarodniki o średniej długości powyżej 18 i poniżej $24 \mu \mathrm{m}$. Według STIELOwa i in. (2011) charakteryzuje go ornamentacja zarodników w postaci wyraźnych brodawek i izolowanych żeber (niepołączonych w niepełną siateczkę), typowe dla tego gatunku są również raczej wysmukłe zarodniki.

\section{${ }^{* *}$ Hymenogaster cf. megasporus Soehner}

Stanowiska: 1. Pod Szkółką, leg. PK i PM, 25.07.2016, KRA F-2016-51. 2. Gróbka, leg. PK i PM, 31.07.2016, KRA F-2016-69, KRA F-2016-73. 3. Upszar (rejon Głębokiego Potoku), leg. PK i PM, 31.07.2016, KRA F-2016-88, KRA F-2016-72, KRA F-2016-84; leg. PC, 31.07.2016, KRA F-2016-78.

Owocniki okrąłe, średnicy do ok. $1 \mathrm{~cm}$; perydium o nieco nierównej, ale niepomarszczonej powierzchni, początkowo białoszare, później ciemne, z dominacją barwy brudnoliliowej; gleba zbita, zbudowana z dużych komór, najpierw białawo fioletowawa, później wyraźnie szarofioletowobrązowa; zarodniki wydłużone, mogące przekraczać $35 \mu \mathrm{m}$ długości, (15)25(37) × (6)13(18), o wydatnym urzeźbieniu, bez papilli.

Uwagi: Znajdowany w otoczeniu drzew liściastych. Według Stielowa i in. (2011), H. megasporus należy do grupy gatunków wykształcających wydłużone zarodniki o średniej długości powyżej $24 \mu \mathrm{m}$, charakteryzuje go ciemne perydium z purpurowym/liliowym odcieniem oraz brak papilli typowej dla zarodników H. citrinus. Zarodniki okazów z Pienin są mniej wydłużone aniżeli w opisie STIELowA i in. (2011).

\section{"Hysterangium clathroides Vittad.}

Stanowisko: 1. Pod Szkółką, leg. PK i PM, 31.07.2016, KRA F-2016-38, KRA F-2016-41.

Uwagi: rośnie najczęściej w lasach mieszanych, związany najprawdopodobniej jedynie z drzewami liściastymi; z Polski podawany tylko z Gorców przez WoJewode i in. (2016). Według MonTECCHIEGo i SARASINIEGO (2000), owocniki H. clathroides są morfologicznie bardzo zbliżone do H. nephriticum, a obydwa gatunki praktycznie nie różnią się wymiarami zarodników. Cechami odróżniającymi $H$. clathroides od $H$. nephriticum są wykształcanie całkowicie plektechymatycznego perydium tworzonego przez grubościenne strzępki oraz delikatnie, ale wyraźnie brodawkowana powierzchnia zarodników (CASTELLANO 1989).

\section{"Hysterangium coriaceum Vittad.}

Syn.: Hysterangium hessei Soehner

Stanowisko: 1. Pod Szkółką, leg. PM, 21.07.2017, KRA F-2017-18.

Uwagi: grzyb związany najprawdopodobniej jedynie z drzewami iglastymi; w Polsce podawany z kilku stanowisk, m.in. z Gór Świętokrzyskich (ŁusZCZYŃSKI 2002, jako H. hessei) oraz Borów Tucholskich i Gorców (ŁaWrynowicz 2001; WoJewoda i in. 2016). Według MonteCCHIEgo i SARASINIEGo (2000) od innych gatunków o pseudoparenchymatycznej budowie perydium odróżniają go krótsze zarodniki (średnia długość poniżej $13 \mu \mathrm{m})$.

Hysterangium crassum Tul. \& C. Tul.

Syn.: Hysterangium clathroides var. crassum Tul. \& C. Tul

Stanowisko: 1. Pod Szkółką, leg. PC, 23.09.2017, KRA F-2017-49. 
Uwagi: rośnie najczęściej w lasach iglastych lub mieszanych; podawany z Gorców (WoJEwodA i in. 2016), ale do tego gatunku prawdopodobnie odnoszą się także inne stanowiska podawane z Polski, w tym z Pienin, pod nazwą H. separabile (GumińsKa 1970, 1972; FlisińsKa 2004). Według MonTeCChIEGO i SARASINIEGO (2000) gatunek charakteryzuje pseudoparenchymatyczne perydium oraz zarodniki o średniej długości powyżej $13 \mu \mathrm{m}$ (podobny $H$. coriaceum tworzy zarodniki długości poniżej $13 \mu \mathrm{m}$ ). MONTECCHI i SARASINI (2000) jako synonim H. crassum podają H. separabile, natomiast CASTELLANO (1989) traktuje obydwa gatunki jako samodzielne taksony.

\section{"Hysterangium nephriticum Berk.}

Stanowiska: 1. Pod Szkółką, leg. PK i PM, 21.07.2017, KRA F-2017-8, KRA F-2017-17, KRA-F2017-18, KRA F-2017-38, KRA F-2017-6, KRA F-2017-19; leg. PK i PM, 25.07.2016, KRA F-201643, KRA F-2016-44; leg. PC, 18.07.2016, KRA F-2016-95; leg. PC, 31.07.2016, KRA F-2016-37, KRA F-2016-45; leg. PC, 23.09.2017, KRA F-2017-43. 2. Gróbka, leg. PC, 16.08.2016, KRA F-2016-25. 3. Dolina Ociemnego Potoku, leg. PC, 11.08.2016, KRA F-2016-22; leg. PC, 27.07.2017, KRA F-201749. 4. Zagroń-Biały Potok, leg. PC, 12.08.2016, KRA F-2016-28, KRA F-2016-24, KRA F-2016-23; leg. PK i PM, 30.07.2016, KRA F-2016-39, KRA F-2016-40; leg. PC, 27.07.2017, KRA F-2017-47; leg. PC, 11.10.2016, KRA F-2016-94; leg. PC, 25.09.2017, KRA F-2017-50; leg. PC, 03.08.2017, KRA F-2017-51.

Uwagi: gatunek spotykany często pod drzewami liściastymi, głównie bukiem, ale związany mykoryzą najprawdopodobniej również z drzewami iglastymi; z Polski podawany jedynie z Gorców (WoJEwODA i in. 2016). Według MonteCCHIEgo i SARASINIEGo (2000) owocniki H. nephriticum są morfologicznie bardzo zbliżone do owocników $H$. clathroides, a obydwa gatunki nie różnią się też wymiarami zarodników. Cechą wyróżniającą $H$. nephriticum jest obecność dwuwarstwowego perydium, w zewnętrznej części plektenchymatycznego, w części wewnętrznej o budowie mieszanej (strzępkowo-komórkowej); wyróżniają go także bardzo delikatnie brodawkowate zarodniki (CASTELLANO 1989).

\section{Hysterangium stoloniferum Tul. \& C. Tul.}

Stanowiska: 1. Pod Szkółką, leg. PK i PM, 31.07.2016, KRA F-2016-42; leg. PC, 23.09.2017, KRA F-2017-44. 2. Upszar (rejon Głębokiego Potoku), leg. PM, 10.10.2017, KRA F-2017-48. 3. Dolina Ociemnego Potoku, leg. PM, 22.07.2017, KRA F-2017-23.

Uwagi: gatunek występuje zazwyczaj w pobliżu drzew liściastych; współcześnie podawany z kilku stanowisk z centralnej i południowej Polski (KuJAwa \& GIERCZYK 2010; WoJEWOda i in. 2016). Według MonTECChIEgo i SARASINIEGo (2000) wyróżniają go zarodniki o średniej długości powyżej $20 \mu \mathrm{m}$, otoczone silnie pomarszczonym perisporium; jego owocniki stosunkowo często są infekowane przez grzyby sprzężniowe z rodzaju Mucor (KoMUR i in. 2019).

\section{"Melanogaster ambiguus (Vittad.) Tul. \& C. Tul}

Stanowiska: 1. Pod Szkółką, leg. PK i PM, 25.07.2016, KRA F-2016-33. 2. Zagroń-Biały Potok, leg. PC, 03.08.2017, KRA F-2017-52.

Uwagi: rośnie pod drzewami liściastymi na nizinach i wyżynach, także w lasach mieszanych w górach; współcześnie podawany z okolic Krotoszyna (PIETRAs i in. 2016) oraz z Lasów Łochowskich (DomAŃsKI 1997). Według MonTECCHIEGO i SARASINIEGO (2000) gatunek wyróżniają charakterystyczne zarodniki mitrowatego kształtu.

\section{"Melanogaster broomeanus Berk.}

Stanowiska: 1. Pod Szkółką, leg. PK i PM, 18.07.2016, KRA F-2016-96; leg. PK i PM, 25.07.2016, KRA F-2016-33; leg. PK i PM, 31.07.2016, KRA F-2016-30, KRA F-2016-31; leg. PC, 23.09.2017, KRA F-2017-45; leg. PM i PK, 21.07.2017, KRA F-2017-4. 2. Gróbka, leg. PC, 16.08.2016, KRA F-2016-3. 
3. Upszar (rejon Głębokiego Potoku), leg. PK i PM, 31.07.2016, KRA F-2016-48, KRA F-2016-35.

4. Dolina Ociemnego Potoku, leg. PM, 22.07.2017, KRA F-2017-2.

Uwagi: gatunek występuje we wszystkich typach lasów, zarówno na nizinach jak i w górach; w Polsce podawany z szeregu stanowisk w całej Polsce, m.in. z Inwałdu, okolic Ińska, Krakowa, Łodzi, Bartoszyc, Gór Buczych, Cieszyna oraz stanowisk na Wyżynie Częstochowskiej, w Gorcach i w Beskidzie Małym (ŁAWRYNOWICZ \& STASIŃSKA 2000, jako M. variegatus var. broomeianus; ZIELIŃSKI i in. 2007; ŁAWRYNOWICZ i in. 2009; KUJAWA \& GIERCZYK 2013; RUTKOWSKI i in. 2014; CHACHUŁA i in. 2015, 2016; WOJEWODA i in. 2016; GIERCZYK i in. 2018).

\section{"Octaviania mutabilis E. Bommer \& M. Rousseau}

Stanowisko: 1. Zagroń-Biały Potok, leg. PC, 12.08.2016, KRA F-2016-4, 25.09.2017, KRA F-2017-55.

Uwagi: rośnie w lasach liściastych i mieszanych, głównie pod bukiem; prawdopodobnie większość stanowisk Octaviania podawanych z Polski jako O. asterosperma (KuJAwa \& GIERCZYK 2010; MLECZKo i in. 2010; ZIElIŃSKI i in. 2011; KoZAK i in. 2013; ChaChUŁA i in. 2015; WoJewOda i in. 2016) dotyczy O. mutabilis. Perydium tego gatunku po uszkodzeniu wyraźnie czerwienieje i/lub zielenieje, a następnie brązowieje, natomiast zarodniki charakteryzują się urzeźbieniem w postaci stożkowatych kolców, do 3,5 $\mu \mathrm{m}$ wysokich. Podobnym gatunkiem jest $O$. lutea $\mathrm{R}$. Hesse, której perydium nie czerwienieje po uszkodzeniu, a rozmiary kolców na zarodnikach dochodzą do ponad $6 \mu$ m wysokości.

\section{DYSKUSJA}

Wyniki uzyskane w trakcie realizacji projektu znacznie poszerzyły wiedzę o mykobiocie grzybów podziemnych Pienińskiego Parku Narodowego. Obecnie znanych jest z tego terenu 35 gatunków grzybów hypogeicznych, w tym gatunki, których nie stwierdzono na powierzchniach objętych badaniami, to jest: Choiromyces meandriformis, Rhizopogon roseolus, Russula mattiroloana, $R$. candidissima oraz Diversispora sporocarpia (GUMIŃSKA 1970, 1972, 1990; JobIM i in. 2019; VIDAL i in. 2019). Trzy spośród wcześniej znanych grzybów podziemnych: Elaphomyces asperulus, Hysterangium crassum i H. stoloniferum, zanotowano również podczas prowadzenia obecnych badań. Warto zaznaczyć, że trzy spośród odnalezionych w PPN gatunków grzybów nie były do tej pory podawane z terenu Polski: Hydnocystis piligera, Hymenogaster cf. arenarius i $H$. cf. megasporus. Pierwszy gatunek jest stosunkowo szeroko rozpowszechniony w Europie, ale jego owocniki są niepozorne i zapewne z tego powodu często przeoczane (ŁAWRYNOWICZ 1988; KUMAR i in. 2017). Według STIELOwA i in. (2011) Hymenogaster megasporus jest gatunkiem rzadko notowanym, ale prawdopodobnie szerzej rozpowszechnionym w Europie Centralnej, podobnie jak H. arenarius. Grzyby z rodzaju Hymenogaster najczęściej tworzą niewielkie owocniki, są to również grzyby trudne do identyfikacji.

Do najszerzej rozpowszechnionych w PPN należały Hysterangium nephriticum i Melanogaster broomeanus - wystąpiły one na czterech spośród sześciu powierzchni. Na trzech powierzchniach pojawiły się owocniki Hydnobolites cerebriformis, Hydnocystis piligera, Hymenogaster rehsteineri, $H$. cf. megasporus, Hysterangium stoloniferum i Gautieria morchelliformis. Grzyby te należały jednocześnie do najczęściej stwierdzanych podczas badań. W przypadku większości, bo aż 21 gatunków liczba zebranych kolekcji nie przekraczała dwóch. Do najrzadziej notowanych należały, między innymi, gatunki z rodzajów 
Chamonixia, Elaphomyces oraz Octaviania, licznie reprezentowane w pobliskich Gorcach, w których odnotowano stanowiska 25 gatunków grzybów hypogeicznych (WOJEwODA i in. 2016). W sąsiednim pasmie górskim nie odnaleziono kilku gatunków trufli, które obecne są w Pieninach: Tuber foetidum, T. fulgens i T. rufum, występuje tam natomiast kilka innych grzybów nieodnalezionych do tej pory w Pieninach: Pachyphlodes citrina (Berk. \& Broome) Doweld, Hydnotrya bailii, Hysterangium pompholyx Tul. \& C. Tul., Melanogaster tuberiformis Corda i Sclerogaster hysterangioides (Tul. \& C. Tul.) Zeller \& C.W. Dodge. Wszystkie z wymienionych wyżej gatunków, z wyjątkiem $H$. bailii, mają w Gorcach pojedyncze stanowiska. Odnotowane różnice w mykobiocie obydwu pasm górskich wynikają niewątpliwie zarówno z odmiennych warunków edaficznych (większa zawartość węglanu wapnia w podłożu), jak i klimatycznych (mniejsza liczba opadów, wyższe średnie temperatury) występujących w Pieninach, jednak, przynajmniej w części, mogą być spowodowane rzadkością tych grzybów. Wspomniane warunki siedliskowe mogą tłumaczyć również duże różnice w różnorodności i bogactwie gatunkowym grzybów podziemnych pomiędzy Pieninami a Bieszczadami. W stosunkowo dobrze zbadanym pod kątem mykologicznym Bieszczadzkim Parku Narodowym odnaleziono stanowiska jedynie sześciu gatunków grzybów podziemnych: Elaphomyces asperulus, E. granulatus, E. muricatus, Melanogaster broomeanus, Octavianina lutea i O. mutabilis (GIERCZYK i in. 2019). Za główny powód tak niskiej różnorodności grzybów z tej grupy w Bieszczadach należy uznać surowszy klimat i, przede wszystkim, kwaśne, krystaliczne podłoże, co znacznie ogranicza występowanie wielu grzybów podziemnych przywiązanych do podłoża wapiennego.

Najbardziej różnorodną mykobiotą w PPN cechowały się powierzchnie 1 (Pod Szkółką), 3 (Upszar, rejon Głebokiego Potoku) i 5 (Zagroń-Biały Potok), na których stwierdzono od 12 do 15 gatunków. Nieco mniej, bo 9 gatunków stwierdzono na powierzchni 2. (Gróbka). Powierzchnie te zostały założone w obrębie zbiorowisk jedliny karpackiej i ciepłolubnej, o stosunkowo zróżnicowanym gatunkowo drzewostanie, obejmującym zarówno drzewa iglaste (jodła, świerk), jak i liściaste (buk, wiąz, grab, leszczyna), co niewątpliwie umożliwiło wystąpienie grzybów o zróżnicowanych wymaganiach co do partnerów mykoryzowych. Powierzchnią, na której nie odnotowano żadnego gatunku grzyba podziemnego w okresie prowadzenia badań, była powierzchnia 6. (Majerz), której drzewostan składał się niemal wyłącznie z drzew iglastych i pochodził z nasadzeń.

Owocniki stwierdzonych podczas niniejszych badań gatunków grzybów stanowią bazę pokarmową dla gryzoni występujących na terenie PPN, szczególnie dla myszarki leśnej oraz nornicy rudej (Komur i in. 2019, 2020). Badania Komura i współpracowników wykazały, że niemal wszystkie grzyby stwierdzone na powierzchniach były obecne w diecie odłowionych gryzoni. Wyjątek stanowiły Hydnobolites cerebriformis i Hydnocystis piligera. Fakt ten można tłumaczyć małą atrakcyjnością dla gryzoni wspomnianych gatunków, które tworzą bardzo drobne i mało mięsiste owocniki.

Wyniki uzyskane w trakcie prowadzenia niniejszych badań stanowią bardzo cenny wkład do znajomości mykobioty Pienin, poszerzają również wiedzę na temat mykobioty Polski. Obok badań prowadzonych w Gorcach, są to jedyne tak szczegółowe badania nad występowaniem grzybów podziemnych w polskich Karpatach, a ich wyniki zachęcają do podjęcia dalszych, bardziej pogłębionych poszukiwań grzybów podziemnych na tym terenie. 
Podziękowania. Badania zostały sfinansowane przez Fundusz Leśny Państwowego Gospodarstwa Leśnego Lasy Państwowe w ramach projektu „Różnorodność i wzajemne powiązania pomiędzy gryzoniami a grzybami podziemnymi i ich wpływ na środowisko przyrodnicze Pienińskiego Parku Narodowego". Autorzy pragną podziękować władzom Pienińskiego Parku Narodowego za pomoc logistyczną oraz Recenzentom za cenne uwagi do manuskryptu.

\section{LITERATURA}

ADAMCZYK J. 1996. Les champignons superieurs des hêtrais du plateau de Częstochowa. Lejeunia. - Revue de Botanique 150: 1-83.

ADAMCZYK J. 2003a. Grzyby wielkoowocnikowe zespołów Tilio-Carpinetum melittetosum i Calamagrostio-Quercetum petraeae rezerwatu leśnego Zielona Góra w północnej części Wyżyny Częstochowskiej. - Ziemia Częstochowska 31: 123-138.

ADAMCZYK J. 2003b. Grzyby wielkoowocnikowe rezerwatu leśnego „Ostrężnik” na obszarze projektowanego Jurajskiego Parku Narodowego (Wyżyna Częstochowska). - Ziemia Częstochowska 30: 177-193.

ADAMCZYK J. 2007. Grzyby wielkoowocnikowe rezerwatu Babsk w województwie łódzkim na tle przemian jego szaty roślinnej. - Parki Narodowe i Rezerwaty Przyrody 26(2): 3-16.

ADAMCZYK J. 2009. Long-term qualitative changes of macrofungi in the light of geobotanical studies in the Babsk reserve. - W: J. HoleKsa, B. BABCZYŃSKa-SANDEK \& S. WiKA (red.), The role of geobotany in biodiversity conservation, s. 137-140. University of Silesia, Katowice.

AdAmczyk J., KurZaC M. \& SieradzKi J. 2008. Macromycetes rezerwatu „Stara Buczyna w Rakowie” w województwie wielkopolskim. - Badania Fizjograficzne nad Polską Zachodnią B, 57: 139-151.

Alvarado P., Cabero J., Moreno G., Bratek Z., Van Vooren N., Kaounas V., Konstantinidis G., Agnello C., Merényi Z., Smith M., Vizzini A. \& Trappe J. M. 2016. Phylogenetic overview of the genus Genea (Pezizales, Ascomycota) with an emphasis on European taxa. - Mycologia 108: 10.3852/15-199.

Castellano M. A. 1989. The taxonomy of the genus Hysterangium (Basidiomycotina, Hysterangiaceae) with notes on its ecology. PhD Thesis, Oregon State University, Corvallis.

ChachuŁa P. 2012. Nowe gatunki grzybów chronionych w Pienińskim Parku Narodowym. - Pieniny - Przyroda i Człowiek 12: 87-101.

ChachuŁA P. 2016. Aktualny stan wiedzy o grzybach chronionych w świetle zmienionych aktów prawnych i stwierdzonych nowych gatunków i stanowisk na terenie Pienińskiego Parku Narodowego. - Pieniny - Przyroda i Człowiek 14: 91-100.

ChachuŁa P. 2018. Grzyby wielkoowocnikowe Dłubniańskiego Parku Krajobrazowego - wstępne wyniki badań. - Przegląd Przyrodniczy 29(2): 58-71.

ChachuŁa P., Dorda A., Fiedor M. \& Rutkowski R. 2015. Grzyby Cieszyna. s. 196. Urząd Miejski w Cieszynie.

ChachuŁa P., Fiedor M., RutKowski R. \& Dorda A. 2020. New records to the mycobiota of the Cieszyn municipality (Polish Western Carpathians) including new species for Poland. - Acta Mycologica 55(1): 5511.

ChachuŁa P., Bodziarczyk J., Kozubek R., Widlak M. \& Siwy M. 2016. Grzyby wielkoowocnikowe występujące w lasach jodłowo-bukowych $\mathrm{z}$ udziałem cisa pospolitego Taxus baccata. - Roczniki Bieszczadzkie 24: 53-85.

Claridge A. \& TRAPPE J. 2005. Sporocarp mycophagy: nutritional, behavioral, evolutionary and physiological aspects. - W: J. Dighton, J. White \& P. Oudemans (red.), The Fungal Community - its Organization and Role in the Ecosystem, s. 599-611. CRC Press. 
Claridge A., Trappe J., Cork S. \& Claridge D. 1999. Mycophagy by small mammals in the coniferous forests of North America: nutritional value of sporocarps of Rhizopogon vinicolor, a common hypogeous fungus. - Journal of Comparative Physiology B 169(3): 172-178.

DOMAŃSKI Z. 1997. Nowe stanowiska rzadkich i interesujących grzybów w Polsce. s. 75. Nakładem Autora, Warszawa.

FLISIŃSKA Z. 2004. Grzyby Lubelszczyzny. Wielkoowocnikowe podstawczaki (Basidiomycetes). 2. s. 88. Lubelskie Towarzystwo Naukowe.

FRANK J. 2005. Complex mutualism in an Oregon white oak woodlands: hypogeus fungi, mycorrhizas and small mammal mycophagy associated with Quercus garryana. MSc Degree Project, Southern Oregon University, Ashland.

FrANK J., BARRY S. \& SOUTHWORTH D. 2006. Mammal mycophagy and dispersal of mycorrhizal inoculum in Oregon white oak woodlands. - General Technical Report PSW-GTR 217: 131-138.

Gierczyk B., Szczepkowski A., Kujawa A. \& ChachuŁa P. 2018. Grzyby projektowanego Turnickiego Parku Narodowego i jego otuliny - wstępne wyniki badań. - W: M. D. BoćKOwsKi (red.), Projektowany Turnicki Park Narodowy. Stan walorów przyrodniczych - 35 lat od pierwszego projektu parku narodowego na Pogórzu Karpackim, s. 175-227. Fundacja Dziedzictwo Przyrodnicze, Nowosiółki Dydyńskie.

Gierczyk B., Kujawa A., Szczeprowski A., Ślusarczyk T., Pachlewski T., ChachuŁa P. \& Domian G. 2019. Macrofungi of the Bieszczady Mountains. - Acta Mycologica 54(2): 1124.

GuMiŃsKa B. 1970. Rzadkie i nowe dla Polski grzyby z rodziny Hysterangiaceae znalezione w Pienińskim Parku Narodowym. - Fragmenta Floristica et Geobotanica 3: 433-442.

Gumińska B. 1972. Mikoflora Pienińskiego Parku Narodowego (część II). - Acta Mycologica 8(2): 149-174.

Gumińska B. 1990. Mikoflora Pienińskiego Parku Narodowego (część V). - Zeszyty Naukowe Uniwersytetu Jagiellońskiego 968, Prace Botaniczne 21: 157-172.

GumińsKa B. 2000. Grzyby wielkoowocnikowe (Macromycetes). - W: J. RAzowsKi (red.), Flora i Fauna Pienin. Monografie Pienińskie 1: 47-53.

Halász K., Bratek Z., Szegö D., Rudnóy S., Rácz I., Lásztity D. \& Trappe J. M. 2005. Tests of species concepts of the small, white, European group of Tuber spp. based on morphology and rDNA ITS sequences with special reference to Tuber rapaeodorum. - Mycological Progress 4: 281-290.

HAwker L. 1954. British hypogeous fungi. - Philosophical Transactions of the Royal Society of London Series B, 237: 430-546.

HilszCZaŃSKa D., Rosa-GruszecKa A. \& Szmidla H. 2014. Characteristic of Tuber spp. localities in natural stands with emphasis on plant species composition. - Acta Mycologica 49(2): 267-277.

Hilszczańska D., Sierota Z. \& Palenzona M. 2008. New Tuber species found in Poland. - Mycorrhiza 18: 223-226.

Jobim K., BŁaszkowski J., Niezgoda P., KozŁowska A., Zubek S., Mleczko P., ChachuŁa P., Ishikawa N. K. \& Goto B. T. 2019. New sporocarpic taxa in the phylum Glomeromycota: Sclerocarpum amazonicum gen. et sp. nov. in the family Glomeraceae (Glomerales) and Diversispora sporocarpia sp. nov. in the Diversisporaceae (Diversisporales). - Mycological Progress 18(3): 369-384.

JüLICH W. 1984. Die Nichtblätterpilze, Gallertpilze und Bauchpilze (Aphyllophorales, Heterobasidiomycetes, Gastromycetes). - W: H. GAMs (red.), Kleine Kryptogamenflora. 2b/1. Basidiomyceten 1. G. Fischer Verl., Jena, Stuttgart - New York.

Kaufmann F. 1925. Die in Westpreussen gefundene Pilze aus den Familien: Pezizaceen, Helvellaceen, Elaphomyceten, Phallaceen, Hymenogastreen, Lycoperdaceen. - Bericht der Westpreussischen, Botanisch-Zoologischen Vereins Danzig 48: 52-62. 
Komur P., Kozak M., ChachuŁa P. \& Mleczko P. 2019. Central European localities, host range and frequency of Mucor rudolphii (Mucorales, Mucoromycota, Fungi), an endoparasite of Hysterangium. - Nova Hedwigia 108(3-4): 465-473.

Kozak M., Mleczko P. \& Ławrynowicz M. 2013. Problem rzadkości grzybów podziemnych na przykładzie Octaviania asterosperma i Chamonixia caespitosa (Boletales). - W: A. BIEDUNKIEWICZ \& M. Dynowska (red.), Interdyscyplinarne i aplikacyjne znaczenie nauk botanicznych. 56. Zjazd Polskiego Towarzystwa Botanicznego, Olsztyn, 24-30 czerwca 2013, Streszczenie wystąpień ustnych i plakatów, s. 327-328. Wyd. Mantis, Olsztyn.

KuĆMIERZ J. 1976a. Flora grzybów pasożytniczych Pienin. Cześć I. Plasmodiophoromycetes, Oomycetes, Chytridiomycetes, Ascomycetes. - Fragmenta Floristica et Geobotanica 22(3): 377-393.

KuĆMIERz J. 1976b. Flora grzybów pasożytniczych Pienin. Cześć II. Basidiomycetes, Deuteromycetes. - Fragmenta Floristica et Geobotanica, 22(4): 605-622.

KuJawa A. 2018. Grzyby makroskopijne Polski w literaturze mykologicznej. - W: M. SNOwARSKI Atlas grzybów Polski. http://www.grzyby.pl/grzyby-makroskopijne-Polski-w-literaturze-mikologicznej.htm (dostęp: 20.12.2019).

Kujawa A. \& GieRCZYK B. 2010. Rejestr gatunków grzybów chronionych i zagrożonych w Polsce. Część. III. Wykaz gatunków przyjętych do rejestru w roku 2007. - Przegląd Przyrodniczy 21(1): 8-53.

Kujawa A. \& GierczyK B. 2011. Rejestr gatunków grzybów chronionych i zagrożonych w Polsce. Część IV. Wykaz gatunków przyjętych do rejestru w roku 2008. - Przegląd Przyrodniczy 22(1): 17-83.

Kujawa A. \& GierczYK B. 2013. Rejestr gatunków grzybów chronionych i zagrożonych w Polsce. Część VII. Wykaz gatunków przyjętych do rejestru w roku 2011. - Przegląd Przyrodniczy 24(2): 3-44.

Kujawa A., Gierczyk B., Kozak M., Mleczko P. \& ŚlusarczyK T. 2017. Różnorodność wielkoowocnikowych grzybów agarykoidalnych, boletoidalnych i hypogeicznych Puszczy Białowieskiej - założenia projektu i wstępne wyniki. - Fragmenta Floristica et Geobotanica Polonica 24(1): 119-131.

Kumar L. M., Smith M. E., Nouhra E. R., Orihara T., Sandoval P., Pfister D. H., Mclaughlin D. J., Trappe J. M. \& Healy R. A. 2017. A molecular and morphological re-examination of the generic limits of truffles in the Tarzetta-Geopyxis lineage - Densocarpa, Hydnocystis, and Paurocotylis. - Fungal Biology 121(3): 264-284.

LÆssøE T. \& HANSEN K. 2007. Truffle trouble: what happened to the Tuberales? - Mycological Research 111(9): 1075-1999.

LubELSKA B. 1953. O występowaniu trufli (Tuber Mich. i Choiromyces Vitt.) w Polsce. - Fragmenta Floristica et Geobotanica 1(1): 87-95.

Luoma D., Trappe J., Claridge A., Jacobs K. \& Cazares E. 2003. Relationships among fungi and small mammals in forested ecosystems. - W: C. ZABEL \& R. ANTHONY (red.), Mammal community dynamics in coniferous forests: management and conservation issues in western North America, s. 343-373. Cambridge University Press.

Ławrynowicz M. 1988. Ascomycetes, Elaphomycetales, Tuberales. Flora Polska, Grzyby, tom XVIII. s. 161 (+27 tablic). Państwowe Wydawnictwo Naukowe Kraków.

ŁaWrynowicz M. 1990. Chorology of the European hypogeous Ascomycetes. II. Tuberales. - Acta Mycologica 26(1): 7-75.

ŁAWRYNOWICZ M. 2001. Macromycetes of oak forests in the Jurassic Landscape Park (Częstochowa Upland) - monitoring studies. - Acta Mycologica 36(1): 81-110.

ŁAWRYNOWICZ M. 2009. Four Tuber species accompanying T. mesentericum in natural sites in Poland. - Anales del Jardín Botánico de Madrid 66S1: 145-149.

ŁaWrynowicz M. 2011. Trufle w Polsce - problemy taksonomii, użytkowania i ochrony. - W: M. ŁAwrynowicz, M. Ruszkiewicz-Michalska \& I. KaŁucKa (red.), Polskie tradycje użytkowania grzybów 
oraz ich ochrony wkładem do europejskiego dziedzictwa kultury. Streszczenia referatów i posterów, s. 75. Sekcja Mikologiczna Polskiego Towarzystwa Botanicznego, Katedra Algologii i Mikologii Uniwersytetu Łódzkiego, Łódź.

Ławrynowicz M. \& Stasińska M. 2000. Macromycetes of the Stellario-Carpinetum in the Iński Landscape Park (NW Poland) - monitoring studies. - Acta Mycologica 35(2): 157-182.

Ławrynowicz M., Dziedziński T. \& Szkodzik J. 2002a. Macrofungi of Aceri-Tilietum and Tilio-Carpinetum in the "Dolina Rzeki Brdy" nature reserve in the Bory Tucholskie (NW Poland). - Acta Mycologica 37(1/2): 63-76.

Ławrynowicz M., DzIEDziński T. \& SzkodziK J. 2002b. Obserwacje mikologiczne w rezerwacie „Dolina rzeki Brdy" w Borach Tucholskich. - W: M. Ławrynowicz \& B. RózGA (red.), Tucholski Park Krajobrazowy 1985-2000, stan poznania, s. 384-405. Wydawnictwo Uniwersytetu Łódzkiego, Łódź.

ŁaWrynowicZ M., ŚLUSARCZYK D. \& WALEWSKA-GrąBCZEWSKA I. 2009. Grzyby projektowanego rezerwatu „Gąszczyk” na Wyżynie Częstochowskiej. - Parki Narodowe i Rezerwaty Przyrody 28(4): 3-16.

ŁUSZCZYŃSKI J. 2002. Preliminary red list of Basidiomycetes in the Góry Świętokrzyskie Mts (Poland). - Polish Botanical Journal 47(2): 183-193.

Mirek Z., Piękoś-Mirkowa H., Zając A. \& ZająC M. 2002. Flowering plants and pteridophytes of Poland. A checklist. - W: Z. MireK (red.), Biodiversity of Poland. 1, s. 442. W. Szafer Institute of Botany, Polish Academy of Sciences, Kraków.

Mleczko P., Kozak M., Ławrynowicz M. \& Dubiel G. 2010. Octaviania asterosperma (hypogeous Basidiomycota) recent data to ecology and distribution. - Acta Mycologica 45(2): 133-144.

Mleczko P., Kozak M., Ławrynowicz M. \& Górszczyk A. 2009. New localities of Chamonixia caespitosa (hypogeous Boletaceae) in Central Europe. - Acta Mycologica 44(1): 29-42.

Montecchi A. \& Sarasini M. 2000. Funghi ipogei d'Europa. s. 714. Associazione Micologica Bresadola, Fondazione Centro Studi Micologici Trento.

Narkiewicz C., Kita W., Pusz W. \& Panek E. 2013. Grzyby i śluzowce. - W: R. Knapik, A. Raj (red.), Przyroda Karkonoskiego Parku Narodowego, s. 339-358. Karkonoski Park Narodowy, Jelenia Góra.

OBERWINKLER F. 2012. Evolutionary trends in Basidiomycota. - Stapfia 96: 45-104.

Ouanphanivanh N., Merényi Z., OrcZán A.K., Bratek Z., Szigeti Z. \& Illyés Z. 2008. Could orchids indicate truffle habitats? Mycorrhizal association between orchids and truffles. - Acta Biologica Szegediensis 52(1): 229-232.

Pancer-Koteja E., Bodziarczyk J., Holeksa J., Piątek G., Różański W., Szwagrzyk J., Kaźmierczakowa R., Dubiel E., Perzanowska J., Wróbel I., Vončina G. \& Zarzycki J. 2004. Vegetation map of the Pieniny National Park, 1998-2001. - W: R. KAŹMIERCZAK (red.), Characteristics and map of plant communities of the Pieniny National Park. - Studia Naturae 49: map.

Paz A., Vidal J. M., Lavoise C. \& Moreau P.-A. 2016. Revisión taxonómica del género Octaviania (Boletales) en Europa. - Boletín Micologico de la FAMCAL 11: 101-138.

Paz A., Bellanger J. M., Lavoise C., Molia A., Ławrynowicz M., Larsson E., Ibarguren I. O., Jeppson M., Lessøe T., Sauve M., Richard F. \& Moreau P.-A. 2017. The genus Elaphomyces (Ascomycota, Eurotiales): a ribosomal DNA-based phylogeny and revised systematics of European 'deer truffles'. - Persoonia 38: 197-239.

Pieniński Park Narodowy. 2019. Przyroda. https://www.pieninypn.pl/pl/ (dostęp: 22.12.2019).

Pietras M., Kujawa A., Leski T. \& Rudawska M. 2016. Grzyby wielkoowocnikowe. - W: W. DanieLEWICZ (red.), Dąbrowy Krotoszyńskie, monografia przyrodniczo-gospodarcza, s. 89-131. Oficyna Wydawnicza G\&P, Gościański \& Prętnicki, Poznań.

Rutkowski R., ChachuŁa P., Fiedor M. \& BeczaŁa T. 2014. Grzyby i śluzowce. - W: R. W. MysŁajek (red.), Monografia przyrodnicza Góry Bucze, s. 29-35. Gmina Brenna, Brenna. 
Schickmann S., Urban A., KräUtler K., Nopp-Mayr U. \& Hackländer K. 2012. The interrelationship of mycophagous small mammals and ectomycorrhizal fungi in primeval, disturbed and managed Central European mountainous forests. - Oecologia 170: 395-409.

Schroeter J. 1898. Die Pilze schlesiens. Erste hälfte. - W: F. CoHN (red.), Kryptogamen-Flora von Schlesien. 3 Band, 1 Hälfte. s. 596. J. U. Kern's Verlag, Breslau.

SIDLAR K. 2012. The role of sciurids and murids in the dispersal of truffle-forming ectomycorrhizal fungi in the interior cedar-hemlock biogeoclimatic zone of British Columbia. MSc Degree Project, The University of British Columbia.

StAsińsKa M. 1994. Macromycetes in recreational park in Łódź. - Acta Mycologica 29(2): 229-236.

Stasińska M. 2000. Rzadkie macromycetes Ińskiego Parku Krajobrazowego. - W: M. LisiEwskA \& M. ŁaWrynowicz (red.), Monitoring grzybów, s. 97-107. Sekcja Mikologiczna Polskiego Towarzystwa Botanicznego, Poznań - Łódź.

Stielow B., Bubner B., Hensel G., Münzenberger B., Hoffmann P., Klenk H.-P. \& GöKer M. 2010. The neglected hypogeous fungus Hydnotrya bailii Soehner (1959) is a widespread sister taxon of Hydnotrya tulasnei (Berk.) Berk. \& Broome (1846). - Mycological Progress 9: 195-203.

Stielow B., Bratek Z., Orczan A. K. I., Rudnoy S., Hensel G., Hoffmann P., Klenk H.-P. \& Göker M. 2011. Species delimitation in taxonomically difficult fungi: the case of Hymenogaster. - PLoS ONE 6: e15614.

SzKodziK J. 2005. Macromycetes in communities of Abies alba on its range border in Central Poland. - Acta Mycologica 40(1): 113-131.

Urban A. 2015. Truffles and Small Mammals. - W: A. Zambonelli, M. IotTi \& C. Murat (red.), True Truffle (Tuber spp.) in the World, s. 353-373. Soil Biology 47. Springer International Publishing, Switzerland.

Vidal J. M., Alvarado P., Loizides M., Konstandinidis G., Chachula P., Mleczko P., Moreno G., Vizzini A., Krakhmalnyi M., Paz A., Cabero J., Kaounas V., Slavova M. \& Llistosella J. 2019. A phylogenetic and taxonomic revision of sequestrate Russulaceae in Mediterranean and temperate Europe. - Persoonia - Molecular Phylogeny and Evolution of Fungi 42: 127-185.

Wojewoda W. 2008. Grzyby wielkoowocnikowe Ojcowskiego Parku Narodowego. - W: A. KLASA, \& J. PARTYKa (red.), Monografia Ojcowskiego Parku Narodowego, s. 317-334. Ojcowski Park Narodowy, Ojców.

Wojewoda W., Kozak M., Mleczko P. \& Karasiński D. 2016. Grzyby makroskopijne Gorców (Karpaty Zachodnie). s. 192. Instytut Botaniki im. W. Szafera, PAN, Kraków.

Zambonelli A., Ori F. \& Hall I. 2017. Mycophagy and spore dispersal by vertebrates. - W: J. Dighton $\&$ J. F. White (red.), The fungal community: its organization and role in the ecosystem. Fourth edition, s. 347-358. Mycology vol. 32. CRC Press.

Zieliński J., AleXandrowicz W. \& ChachuŁa P. 2011. Ścieżkami Pańskiej Góry. Wydanie drugie. Urząd Miejski w Andrychowie, Andrychów.

Zieliński J., Biel-Pająowa M., Alexandrowicz W., Walusiak E. \& ChachuŁa P. 2007. Wapiennik w Inwałdzie. Ścieżka przyrodnicza. Urząd Miejski w Andrychowie, Andrychów.

\section{SUMMARY}

Hypogeous fungi are characterised by specific morphological and ecological adaptations. Their spores develop inside completely or partially closed sporocarps that mature in the ground. Most of these fungi have lost the mechanisms of active spore discharge and the possibility to disseminate them via air. Thus they rely on vector organisms such as arthropods, molluscs and vertebrates, primarily mammals, for 
long-distance spore dispersal. Hypogeous fungi play an important role in food chains, as a food source for mycophagous animals and as symbiotic partners in mycorrhizal associations with plants, mostly trees.

There is little information available about the diversity and distribution of hypogeous fungi in the Pieniny Mts. Previously only eight species were reported from this area: Choiromyces meandriformis (LUBELSKA 1953, as C. venosus), Elaphomyces asperulus (GuMIŃsKa 1990), Rhizopogon roseolus (GUMIŃsKa 1972), Hysterangium crassum (GUMIŃsKA 1970, 1972, as H. separabile), Hysterangium stoloniferum (KomUR et al. 2019), Russula mattiroloana, $R$. candidissima (VIDAL et al. 2019) and Diversispora sporocarpia (JoвIм et al. 2019).

The aim of the present study was to gather new data on the hypogeous fungal mycobiota of the Pieniny Mts, especially as a source of food for small mammals. The research was part of a project entitled "Diversity and interactions between rodents and hypogeous fungi, and their influence on the natural environment of Pieniny National Park" financed by the Forest Fund of the National Forest Holding.

The sporocarps of hypogeous fungi were searched on six permanent plots established in Pieniny National Park (Tab. 1, Fig. 1), in July and September of 2016 and 2017. The dominant plant associations were fir forest Dentario glandulosae-Fagetum abietetosum and Carici albae-Fagetum abietetosum, with spruce, beech, hazel, hornbeam and elm as accompanying trees (Tab. 1). The sporocarps were identified by classical methods employing contemporary mycological keys and monographs. The exsiccates were deposited in the Herbarium of the Institute of Botany, Jagiellonian University in Kraków (KRA).

During the field work more than 100 samples of hypogeous fungi were gathered. They included 30 species of ascomycete genera: Elaphomyces (3 species), Genea (1 species), Hydnobolites (1 species), Hydnocystis (1 species), Hydnotrya (1 species), Leucangium (1 species), Pachyphlodes (1 species), Tuber (4 species), and basidiomycetes: Chamonixia (1 species), Gautieria (3 species), Hymenogaster (5 species), Hysterangium (5 species), Melanogaster (2 species) and Octaviania (1 species) (Tab. 2). Two species, Hysterangium nephriticum and Melanogaster broomeanus, occurred on 4 out of 6 plots, and another six species were found on 3 plots: Hydnobolites cerebriformis, Hydnocystis piligera, Hymenogaster rehsteineri, H. cf. megasporus, Hysterangium stoloniferum and Gautieria morchelliformis. The specimens of these species were also most often collected. More than 20 species were collected only once.

The hypogeous mycobiota of the Pieniny Mts now numbers 35 species. There the diversity of species is similar but higher than that recorded in the nearby Gorce Mts. Certain species, mostly Tuber spp., were not found in the Gorce Mts, and some species of the latter range were infrequent or not recorded in the Pieniny Mts. The recorded differences most probably are the consequence of differences in edaphic and climatic conditions between the two ranges.

Wptynęto: 15.11.2019 r.; przyjęto do druku: 30.12.2019 r. 